\title{
Futebol, poesia e drama: o espetáculo
}

Renata Pallottini*

Professora titular da Universidade de São Paulo. É doutora (1982) e graduada em Artes Cênicas (1964) e em Direito (1953) pela Universidade de São Paulo, e em Filosofia pela Pontifícia Universidade Católica de São Paulo (1951). Tem experiência na área de Comunicaşão, com ênfase em Artes Cênicas.

E-mail: rpallott@uol.com.br

Resumo: O que seria necessário para que se pudesse dizer que uma partida de futebol semelha de alguma forma a um espetáculo teatral, poético, emocional? $\mathrm{O}$ artigo propõe um passeio livre pela história dos diferentes tipos de teatro e pelas mudanças sofridas ao longo dos anos. A autora lembra que existe, da metade do século passado para cá, uma nítida divisão que colocou em campos opostos o teatro dramático e o teatro épico, o drama rigoroso contra o texto quase absolutamente livre, Aristóteles contra Brecht. E volta a apresentar as razões pela qual se pode afirmar que existem certos momentos no futebol que o aproximam ainda mais do espetáculo teatral, da dança, da comédia e do drama.

Palavras-chave: futebol, teatro, poesia, drama, ficção.
Abstract: What would be necessary so that one can say that a soccer game resembles, in some way, a theatrical, poetic, emotional spectacle? The article proposes a free ride through the history of different types of theater and the changes that occurred along the years. The author reminds that there is, since the half of last century, a clear division that put the dramatic theater and epic theater into opposite fields, the rigorous drama against the almost completely free text, Aristotle against Brecht. She introduces again reasons why it can be stated that there are certain moments in soccer that approach it even more to the theatrical spectacle, dance, comedy and drama.

Keywords: soccer, theater, poetry, drama, fiction.

Como é certo que de tudo se pode fazer poesia, e como a poesia pode ser lírica, épica ou dramática, fica implícito que de futebol se pode fazer poesia, cinema, teatro. De boa qualidade, mediano, ou sucesso de bilheteria. Mas sempre mostrando a nós, povo brasileiro, imerso nesse jogo fantástico que nos traz alegria ou lágrimas, que é fonte de emoção, de cólera ou felicidade, mas, de qualquer modo, de um movimento de alma, descarga, catarse.

Meu primeiro momento de poesia lírica que tinha a ver com futebol aconteceu em 1977, quando, depois de uma espera de mais de vinte anos, o Corinthians, meu clube do coração, conseguiu ganhar, finalmente, um campeonato.

Fui para a Avenida Paulista, como toda gente que se prezava; gritei, cantei e comecei a pensar no que seria aquele mundo de povo, em plena ditadura, gritando os slogans a que tinha direito e começando por derrubar as traves do gol, depois os alambrados, depois os portões do Morumbi e, por fim, os

Recebido: 05/06/2009

Aprovado: 08/06/2009

* Disponível em: $<$ http://lattes.cnpq. br/4694028146994138>. 
comunicação \& educação • Ano XIV • Número 3 • set/dez 2009

símbolos do poder e da força. Era muito sonho, mas, em todo caso, nada me impedia de sonhar.

O poema começava assim:

São onze contra onze

e o povo em frente...

É o jogo da bola

e o povo enfrenta...

Para quem não sabe, onze são os jogadores de cada time; e o povo, nos estádios de todo tipo - naquela noite o Morumbi com mais de oitenta mil pessoas -, fica, metaforicamente, em frente, ou seja, formando o público que assiste a uma representação, numa espécie de teatro ao ar livre, às vezes circular, às vezes retangular, de formas variáveis.

É, afinal de contas, um espetáculo dramático, com cenário, luzes, indumentária, personagens, público, algumas regras fundamentais e uma espécie de metteur en scène, que é o juiz. Os líderes de cada um dos grupos são os treinadores, pedantemente apelidados de técnicos.

Explicando melhor: o cenário é o quadrilátero de grama, de 120 metros (ou 90, no mínimo) de extensão, por 90 metros (ou 75, no mínimo) de largura. Todo demarcado com tinta branca, mostra os seus próprios limites, fora dos quais, a rigor, não ocorre o jogo (quando a bola sai de cena, deve ser reposta observando-se algumas formalidades que não vêm ao caso). Dentro do campo propriamente dito, ocorrem outras marcas, uma delas dividindo o campo ao meio, de modo a que pertença, teoricamente, metade a cada equipe. Dentro dessa chacrinha de cada time, existem ainda outras duas linhas, em forma de $U$ (aproximado, não sejamos exigentes), que são a grande área e a pequena área. Temos ainda, nos extremos de cada lado do campo, de novo retangulares, os dois alvos, metas, arcos, gols propriamente ditos. Botar a bola dentro deles que são formados por traves de madeira (ou similar) e uma rede, metas que têm 7,32 m de largura e 2,44 de altura - é o objetivo do jogador oponente.

Os figurinos são, hoje em dia, calções pouco acima dos joelhos e camisetas que, pela cor e pelos ornamentos, identificam o time a que pertencem. Usam-se sapatos especiais, cada dia mais especiais, e meias que cobrem caneleiras protetoras e vão até pouco abaixo dos joelhos.

Falta alguma coisa para que se possa dizer que uma partida de futebol semelha de alguma forma a um espetáculo teatral, poético, emocional? Faltam muitas. Temos cenário, figurinos, luzes, som, atores e diretores (que são os jogadores, juízes e técnicos, primordialmente), temos público. Mas será que temos texto?

O que é um texto teatral, hoje em dia? Como tudo na vida, o teatro muda no compasso das mudanças sofridas por todas as artes, pelos artistas e pela realidade. O texto já foi, a seu tempo, uma peça literária de bom estilo, que podia ser lida com prazer, mesmo sem o espetáculo previsto pelo próprio texto, e que devia servir de fonte para a interpretação de atores, fiéis o quanto possível à letra dessa criação literária. 
Já houve tempo, por outro lado, em que o texto quase não existia. Os fazedores do espetáculo memorizavam um roteiro breve e, a partir deste, improvisavam, seguindo velhas normas e costumes que atores/personagens fixos conservavam e passavam adiante. Mesmo sem texto escrito, o público se divertia e emocionava-se, e os atores não deixavam de brilhar e de mostrar seu talento e sua capacidade de integrar-se de tal maneira ao espírito do espetáculo que compunham e improvisavam sem romper a continuidade e a coerência necessária àquele tipo de teatro.

Falo daquele tipo de teatro porque existem incontáveis tipos; o teatro já foi uma extensão de cerimônia ou momento religioso, já foi um quase-balé ou um quase-recital de música, já se propôs ser absurdo (logicamente absurdo, ou seja, provando pela melhor lógica que o mundo é absurdo), já foi feito em prosa de boa qualidade, ou todo em versos metrificados e rimados; pretende ser filosófico, político, às vezes didático pelo efeito único do riso. Em geral é dialogado, mas pode ser monologado, ou seja, feito por um único ator; pode ser todo ou parcialmente musical, como as óperas, operetas, zarzuelas e comédias musicais; pode ser para rir ou para chorar, mas...

... É preciso dizer que existe, da metade do século passado para cá, uma nítida divisão que colocou em campos opostos o teatro dramático e o teatro épico, o drama rigoroso contra o texto quase absolutamente livre, Aristóteles contra Brecht. Um pretendia que, a partir de uma ideia central, se construísse um script exigente, guardador de certas regras, de preferência passado em período de tempo curto - o tempo do conteúdo, claro -, com poucos personagens, cada qual deles portador de um objetivo a ser alcançado. A luta por alcançar o objetivo poria esses personagens em conflito, daí resultando um movimento interno que se chama ação dramática; viria, por consequência, a evolução e, por fim, o desenlace ou desfecho.

O outro teórico da dramaturgia (além de dramaturgo), Bertold Brecht, mercê de seu interesse por um teatro primordialmente transformador da situação social, dava de ombros para tais regras e propunha um texto básico mais livre, menos voltado a exigências formais e que, utilizando narrações, suportes visuais, música ou o que quer que fosse necessário, alcançasse o fim transformador a que se propunha. Revolucionário, o teatro brechtiano (que, aliás, já tinha antecedentes) não prescindia do conflito e da evolução necessária da ação dramática.

Mas a coisa não parou por aí; nem poderia, estando a Arte, como a vida, em perpétua transformação. Surgiu, entre outras propostas, o que se chamou pós-moderno, movimento em que a fidelidade ipsis litteris a um texto dramático pareceria quase falta de imaginação. Os tempos eram outros e demandavam formas novas.

Os espetáculos mais recentes, em todo o mundo, mostram adaptações que se multiplicam, a partir de legítimas peças de teatro, brotando do que se poderia chamar criação coletiva, oficinas, exercícios de improvisação, desejos de atualização e ideologização etc. Discute-se até a natureza da adaptação, 
questionando-se a sua legitimidade, os limites a que se deveria ater, ou a total inexistência de limites.

Ou, então, os novos espetáculos mostram textos inéditos, retratos de uma nova realidade, fragmentária, destituída de compromissos com os liames de causa e consequência, atentos apenas à representação de um mundo permanentemente em guerra, seja no campo individual, seja no social e político.

Não são estes exercícios dramáticos o total da produção de teatro, mas são, neste momento, sua maioria. Estabelece-se, quando muito, uma linha de ação principal, que é a portadora do que se poderia chamar ideia central do texto. Os personagens têm seus objetivos, que perseguem através do texto dramático. Continuam a existir personagens que enfrentam personagens, em constantes conflitos, que terminam por solucionar-se, de uma ou de outra maneira.

Exemplo de ação principal, de ações secundárias, de objetivo, de ideia central? O clássico Romeu e Julieta.

Romeu Montecchio e Julieta Capuleto são cidadãos de Verona, cidade da Itália, e a ação se desenvolve no Renascimento; os dois jovens, depois de um baile realizado no palácio Capuleto, percebem que estão enamorados e que seu amor é profundo e para sempre. Pretendem casar-se; seu objetivo, que perseguem durante todo o decurso do drama, é o de conseguir realizar o seu amor.

Mas os Montecchio e os Capuleto, famílias de ambos, são inimigos mortais; jamais permitirão que dois representantes de suas estirpes venham a amar-se e unir suas vidas. Portanto, opõem-se ao desejo dos jovens. Buscam, inclusive, com urgência, um bom noivo para Julieta; e depois que Romeu, provocado em sua honra, mata Teobaldo, da família Capuleto, providenciam para que o moço seja desterrado, de Verona para a cidade de Mantua.

Os jovens amantes são, portanto, os portadores da ação principal; têm um objetivo e querem alcançá-lo: desejam unir-se e tornar realidade o seu amor.

As famílias inimigas, paradoxalmente unidas, agora, opõem-se aos desejos dos protagonistas e travam contra eles a batalha principal da peça. Os acontecimentos se precipitam; há personagens secundários que acompanham um ou outro lado do conflito, o qual termina com a morte dos jovens e a reconciliação dos velhos. Este desfecho poderia ser a tradução da ideia central: $a$ desavença dos velhos sacrifica os jovens, o que é, afinal de contas, a definição de todas as guerras.

Mas voltando ao futebol: dissemos que lhe falta, para configurar mais fortemente um espetáculo teatral, o texto. E é certo, embora tenhamos sempre, ao início de cada partida, a apresentação da lista de atores/personagens, a chamada escalação do time, que, se referidos atores forem de agrado do público, é, muitas vezes, seguida de aplausos e manifestações de agrado.

Não falta também, no cerne da própria partida, às vezes chamada de combate, pugna ou mesmo batalha, o caráter básico de conflito. Não esqueçamos que são "onze contra onze e o povo em frente!". O importante, aí, é a palavra contra. Não se trata de uma mera exibição de talento, preparação física, habilidade. Também não se faz aqui, como em outras variedades do desporto, exibições 
individuais, consecutivas. Quem voa mais no salto em altura? Isso se verá ao fim de muitos saltos de vários participantes.

Aqui, não. Os jogadores, vinte e dois, estão em campo e, ao mesmo tempo, cada vez que estejam de posse da bola, ou em posição de conquistá-la, lutarão para conservá-la, mover-se com ela em direção ao campo contrário e, finalmente, marcar um gol, ou seja, colocar a bola dentro da meta adversária. Trata-se de um esporte coletivo.

É, realmente, uma disputa acirrada, movida por forças de tipo variado. O conflito existe, mas qual é o objetivo? Que querem os combatentes? Basicamente, a vitória. Mas qual é o significado dessa vitória?

A vitória, seja ela qual for e seja qual for o caráter da pugna que a precedeu, é sempre engrandecedora. No caso da diegese, da história exposta na obra de ficção, a vitória é também ficcional: Romeu e Julieta perdem a batalha (embora se possa dizer que seu amor, idealmente, permanece vivo); Édipo vence, ao desvendar o mistério proposto, mas tem uma vitória amarga, destruidora, que o cega. $\mathrm{O}$ mesmo sucede a Zé do Burro, protagonista de $O$ pagador de promessas, de Dias Gomes, que consegue fazer entrar na igreja a cruz que prometera levar, mas entra morto. Essas são as vitórias e derrotas diegéticas, contidas na ficção, que embasam as peças de teatro.

Não há ficção no espetáculo/jogo de futebol. Os contendores se enfrentam tomados pela realidade; pretendem vencer e se esforçam para isso. Sua vitória lhes proporcionará certos prêmios, que podem ser simbólicos (uma taça, uma medalha) ou mais prosaicos, como um melhor contrato para mudar de clube, uma quantia em dinheiro, fama, celebridade.

No entanto, existem certos momentos no futebol que o aproximam ainda mais do espetáculo teatral, da dança, da comédia, do drama. É frequente ver jogadores reunidos para representar a alegria, quando um deles marca o gol. Em conjunto, dançam, fazem mímicas de tipo variado, cada uma com seu sentido, com seu significado: celebram o nascimento de uma criança, imitam um animal ou mandam mensagens a pessoas queridas. Essas representações não são improvisadas; em geral, foram ensaiadas e são repetidas no momento oportuno.

Por outro lado, é comum ver que certos jogadores/atores fazem algo mais do que avançar para o campo contrário, levando a bola ou lutando para consegui-la. É famoso o caso do jogador Garrincha, um ponta-direita brasileiro memorável, que gostava de bailar diante do adversário, num lance cheio de conteúdo que pretendia, além de enganá-lo, zombar dele. Os jogadores que contracenavam com ele, se fossem bons profissionais, procuravam respeitá-lo em sua habilidade. Atualmente, sabe-se que o jogador que quiser imitar o velho ídolo corre o risco de ser agredido, porque o espetáculo da habilidade faz com que o adversário se sinta diminuído e ofendido.

Há momentos de poesia no espetáculo futebolístico. Se um jogador cair em campo, atingido por um adversário ou simplesmente por um mal súbito, é quase obrigatório que a bola seja lançada voluntariamente para fora de campo e se paralise o jogo a fim de que o contundido seja socorrido. Igualmente, depois 
que tudo se normaliza, a equipe que jogou a bola para fora é premiada com o retorno a seu favor. E, se o acontecimento for realmente sério, é fatal que todos os jogadores se reúnam ao redor do ferido e chamem, insistentemente, um médico, qualquer médico, para o socorro.

É poesia, também, ver um jogo importante, interestadual, internacional, ser interrompido pela entrada de um cachorro no gramado. Ou pela simples invasão de campo por um torcedor entusiasmado (o chamado entusiasmo dionisíaco); há, inclusive, no jogo de futebol, narradores de rádios e TVs que inventam expressões únicas e cheias de encanto: chamam a bola de menina; o canto da meta, onde as traves se encontram, é o lugar onde a coruja faz seu ninho; quando um jogador chuta a bola para longe, diz-se que jogou a bola prô mato, porque o jogo é de campeonato.

E, provando nossa tese, é preciso lembrar sempre a voz do locutor de rádio Fiori Gigliotti (1928-2006), que toda vez começa suas participações dizendo com voz possante: "Abrem-se as cortinas e começa o espetáculo, torcida brasileira!". 